\title{
Mapping the Estonian Literature of the Selfie-era ${ }^{1}$
}

\author{
ANNELI KÕVAMEES
}

\begin{abstract}
We live in the era of selfies as making photos of oneself and sharing these in social media has become extremely popular if not even a norm. The perceiving and experiencing subject is in the foreground. This is also valid in the field of literature, which has been democratized as anyone can make a book and anyone can write a book, as seen by the boom of biographies of all kinds. The My-series published by the Estonian publishing company Petrone Print illustrates these tendencies. The publishing company was founded in 2007 by Epp Petrone who had moved back to Estonia from the United States. Her My America was the first book in the series. In this series of books authors describe their lives and activities in one country or city. The series has a firm position in the Estonian literary field: the books are constantly in top ten lists and are in high demand in libraries. Taking the My-series as an example, the article maps tendencies in contemporary Estonian literature. The subject-centeredness is one of the characteristics of contemporary literature as the amount of books concentrating on one's life experiences is quite noteworthy. The exact genre of this type of literature is ambiguous, which is another characteristic of contemporary literature. I would define the My-series books as 'literary selfies' as the person portrays him/herself setting the world in the background. Another issue discussed in connection with the series is migration. The demographic situation in Europe has changed and continues to change; various nationalities can be found in the world metropolises, and the shift from the monocultural and monolingual world to the multicultural and multilingual one is obvious. Therefore, more and more people have a 'hyphenated identity'; consequently, one's national identity may not be as clear as before. Over the last decade, a large number of Estonians have left their homeland and settled down in other countries, an aspect illustrated by the My-series.
\end{abstract}

Keywords: travel literature; the My-series; the 2000s; the 2010s; Estonian literature

This study was supported by the Estonian Ministry of Education and Research (IUT 18-4), and by the European Union through the European Regional Development Fund (Centre of Excellence in Estonian Studies). This is a revised version of the article “Petrone Prindi „Minu“ sari: selfie-ajastu kirjanduse kaardistusi” published in Philologia Estonica Tallinnensis (Kõvamees 2017).

DOI: https://doi.org/10.12697/IL.2019.24.2.7 
Mapping the Estonian Literature of the Selfie-era

\section{Introduction}

It may be said that in contemporary society the perceiving and experiencing subject is in the foreground. Especially in connection with the millennials the term me-centredness can be used (see e.g. Stein 2013). The technological progress allows one to consume various products and services when it suits the individual and the way it suits him/her, e.g. watching TV-programmes, ordering a taxi or goods, etc. The rapid technological progress allows everyone without a special training to operate successfully in the fields where it was not possible only some decades ago; one of the most significant examples is photography. ${ }^{2}$

Everyone's experience is found to be worthy of being shared, so that it is possible to be part of people's everyday activities, thoughts, feelings, or in other words to be part of the everyday reportages of people. Everyone can create his/ her own world and be the centre of that world, therefore, the experiencing subject is in the foreground. This tendency is also noticeable in the literary field where all sorts of biographies, memoirs and travel books play a substantial role. Literature has been democratized as everyone can write and publish a book and everyone can be the subject of a book. This aspect is especially emphasized already in the titles of the My-series books. Concentrating on the My-series books published by the publishing company Petrone Print, the article maps some of the tendencies in contemporary Estonian literature keeping the principles of imagology in mind. How to explain the phenomenon of the series? What elements are found in these books that also characterize contemporary Estonian literature? What about the genre of this type of books?

2 "I take a photo, therefore I am" could be one of the leading ideas of the contemporary world, which can be characterized as the selfie-era, as making selfies has become massive and a selfie and a selfie-stick are the keywords characterizing the era. (The Oxford English Dictionary named 'selfie' the word of the year 2013 (see also http://blog. oxforddictionaries.com/2013/11/word-of-the-year-2013-winner/). Every moment has to be photographed and more importantly that captured moment has to be shared in social media. It has been noted that today the default state of photographs is sharing (Tiidenberg 2015: 121). The era of photography is coincident with the era of mass tourism while the latter helped to "create an appetite for tourism" (Stavans, Ellison 2015: 109). Photos are an important component in the My-series as several books that initially did not have photo pages have been re-issued with photos. Illustrative material has a significant role in the image of the country as it complements the text. Therefore, the role of photos cannot be underestimated and it is worth a special study. 


\section{The My-series: Background and Goals}

The publishing company was founded in 2007 by Epp Petrone (born in 1974) who had moved back to Estonia from the United States. In the My-series authors describe their life and happenings in one country or city. The Myseries books are based on the non-touristic travel experiences. The authors have lived a longer period in the country they are writing about and for that reason they see beyond the tourist tracks, describing daily life, for example there are detailed descriptions of shopping, searching for accommodation, etc. More than one hundred books have been published hitherto and the number is growing. The first book in the series was Epp Petrone's Minu Ameerika (My America, 2007), which is among the ten bestselling books of the series (Rudi 2014). ${ }^{3}$ Most of the books are written about Europe but during the last years the area has widened considerably. ${ }^{4}$ The majority of the authors do not have a literary background, they represent various fields. ${ }^{5}$ The founder of the publishing company has stated that the goal of the series is to find different types of people and lifestyles, so that each book not only depicts one country but also one subculture (Salong 2010). She has also stressed the ethnologicalsociological aspect of the series (Petrone 2010) and the fact that the goal of the series is not to produce books worthy of the Nobel Prize but to portray Estonians in the current era (Rudi 2014). The founder of the company believes that this is the way readers take these books: they are forgiven more than real writers as they offer something else - a sincere look into the true world of one's self (Petrone 2010).

Thus, publishers have defined the direction and position of the series, not aiming to produce high literature as the literary high points are seen as an extra bonus (Petrone 2010). They have found their niche and readers. In the discussion about the Noughties, held primarily in the articles published in the literary magazine Looming, Tiit Hennoste noted "Do readers search from

3 My Estonia (2009) by Justin Petrone has the first position (Rudi 2014). The vast majority of books in the top ten list are from the earlier period of the series.

4 For the overview of published books see https://petroneprint.ee/kategooria/minu/. In connection with the $100^{\text {th }}$ anniversary of the Estonian Republic a series of books were published depicting various places in Estonia, e.g. My Muhumaa (2018), My Pärnu (2018), My Setomaa (2019), etc. While in the majority of the My-series books Estonian authors depict foreign countries (the term hetero-image can be used), in these books Estonians depict Estonia (the term auto-image can be used). This auto-image will be the subject of a special study.

5 There are exceptions, for example My Nenets Land (2010) by Olev Remsu, My Brussels (2011) by Vahur Afanasjev, My France (2013) by Eia Uus, My Latvia (2016) by Contra. 
literature something else than they search from television, journalism, internet? It seems that they do not. This means that art does not have a place here. Art is not necessary for that experience [...]" (Hennoste 2009: 1280). ${ }^{6}$ This is one of the tendencies characterising the contemporary society: a considerable amount of readers look for a non-complex story written in an uncomplicated language. Eat. Pray. Love. One Woman's Search for Everything Across Italy, India and Indonesia (2006) by Elizabeth Gilbert is a good example while the subheading also summarizes very well one important trend in the My-series.

\section{Me and My World}

Namely, the majority of the My-series books are written by women whose main reason for leaving their homeland has been dissatisfaction with their lives. Therefore, they have decided to change their lives and go abroad, which in several cases turns out to be a long-term presence. It is not unusual that several women find their true love and thus they remain living abroad. In the new environment and in the new situation one starts to see oneself and the world differently and this experience is shared with readers. Encountering the other culture/society, one's identity and values are reconsidered (see also Liiv 2012: 85). Gradually more fundamental differences become noticeable. The more foreign the other culture, the sharper is the initial confrontation and also the cultural shock. The adaptation process has a vital role and influences significantly the way the other culture is seen. In a new culture or society one has to "rebuild" oneself, has to find one's place or as Michel Butor has noted "[one] will need to begin learning to read once more" (Butor 2001: 76): foreign culture is read like a foreign text whereas at the beginning it is difficult but in the end one feels free both in the foreign language and culture, the once foreign becomes familiar. One can turn into a local (see also Kõvamees 2013: 86), meaning accepting certain behaving and acting models which mark belonging to that culture. It can be something simple like writing an address in a certain way (see My England, Alari 2012: 265) or for example mastering a special way of moving: the author of My Japan notes that she "moves around like a native resident of Tōkyō (Yano 2013: 103). However, turning into a local means more fundamental changes, resulting in the altering of one's self. In the end a double-identity may develop, meaning the author feels at home in both cultures. Nevertheless, it is only possible to become a near native as it is not possible to become a real native, there will always be something different. This

6 Here and henceforth my translation - A.K. 
is the fact several authors state, for example the author of My Italy has noted "No matter how well one knows the history and society of the other country, in every culture there are things that are understandable only to those born within that culture" (Praakli 2009: 167).

While the majority of the books depict the settling down in a foreign culture and also finding a second home, there are some cases where foreign remains foreign, for example the author of My Vietnam notes "I wanted to be accepted as one's own but I was and remained a foreigner and that was made clear in a pretty painful manner" (Kallas 2012: 276). The most extreme example is My Albania where the author states that "for locals I was and remained of foreign blood" (Vela 2012: 221). The image of the country is strongly affected by the domestic violence experienced by the author. The story becomes a psychological thriller distinctly differentiating from other books in the series. ${ }^{7}$

Travelogues offer the possibility of following the author on her/his spiritual quest. Usually the following structure is detectable: at the beginning of the book the author has several questions about his/her (personal) life, which may have reached a crisis, whereas by the end of the book the author has answers even to those questions s/he did not ask. In the end one has become wiser and has found inner peace. In other words, the coming-of-age story or the term Bildungsroman may be used, for example Justin Petrone's My Estonia may be interpreted as a classic "boy becomes a man story" where the birth of a child is a significant milestone (see Petrone 2011: 352). It is characteristic of the Myseries books that the author looks back to his/her former self as a layman (Liiv 2012: 36), meaning the one who tells the story has more authority than the other whom the story is about or the one who acts in the past. The goal is to emphasize personal development: who the author once was and where $\mathrm{s} / \mathrm{he}$ is by the time of writing the book (Liiv 2012: 37).

In most cases the final destination is inner peace and a way of life valuing simple pleasures, for example the author of $M y$ Copenhagen notes "It took some time to realize how to live without excessive worrying but in the end I managed it. [...] At length I am accustomed to hygge ${ }^{8 ”}$ (Nielsen 2013: 12). Some other

\footnotetext{
The aspect of objectivity was set in the foreground in the reception of the book (see the web page of the publishing company http://petroneprint.ee/raamatud/minualbaania/). Several comments failed to notice that My Albania did not set the goal to give an objective depiction of the country but represents this author's subjective image of the country, which is also noted in the title of the book.

8 Authors often use specific terms from that language to mark certain aspects, for example poco-poco ('little by little) in My Guatemala (Kahu 2011: 148), jeitinho brasileiro in My Brazil (Gerhold 2012: 147).
} 
examples: the author of My Italy concludes "Italy has taught me to value family and friends, to notice important things around me and taught me to be happy about small things and notice even the tiniest details" (Praakli 2009: 319-320) and the author of My Sicily states that "The most important thing is satisfaction with oneself and I have that here" (Merusk 2012: 245). The majority of authors are women whose narrative, as Kate Cantrell has noted, "emphasizes a desire for personal growth and balance, employs travel as the register for this selfrealisation" (Cantrell 2011: 46). The most well-known example is Eat. Pray. Love by Gilbert. ${ }^{9}$

A large number of the My-series books can be read as self-help books in the style of Gilbert but the best examples do not deal only with the writer's personality, offering also insights into contemporary society. One of the topics discussed is globalization and the fact that we are living in the era of hyphenated identities, ${ }^{10}$ for example: "The citizen of the new Europe speaks different languages and feels at home in most of the member states. [...] The larger the "global village" grows, the more "the multicultural salad" is the norm" (My Amsterdam, Roose 2011: 274). Being a world citizen characterises the Myseries books, which has been noted to be the indicator of the new generation of Estonians who can sing "I am an Estonian and I will remain an Estonian"11 one day and the next fly to the other side of the world and continue their lives there. They are Estonians but they are also Europeans and world citizens to whom this is normal, which is a sign of the globalizing world (Hellerma 2009). The world is right here, only a few flying hours or mouse clicks away. Besides writing, travelling has also been democratized as until the second half of the $19^{\text {th }}$ century only members of the elite could travel, so travelling marked a

9 Those who have been more critical have noted that "this narcissistic New Age reading" uses a stereotypical image of the East, which is associated with spirituality and deepness where well-off white women can find themselves (Callahan 2007). Gilbert's book emphasizes living fully and can be seen as an invitation for self-discovery. It has launched a whole industry offering the possibility to take a similar journey but in reality only a few can afford it (Sanders, Barnes-Brown 2010). The book has a peculiar copyDrink, Play, F@\#k: One Man's Search for Anything Across Ireland, Vegas and Thailand (2009) by Andrew Gottlieb. A parodic answer to similar texts in Estonian is Eesti naise onn [Estonian Woman's Happiness] (2009) by Jaak Urmet under the pseudonym Grete Márquez.

10 Hyphenated-identity is a term used to mark someone who has more than one national identity e.g. British Asian, African American, etc. (Thompson 2011: 5).

11 Reference to a popular song from the Estonian Singing Revolution era written by Alo Mattiisen (music), Jüri Leesment/Karl August Hermann (lyrics) and performed by Ivo Linna. 
special social status. This changed with the coming of railways (Urry 2002: 16). Today travelling does not mark belonging to the elite as it is possible to travel with a minimum budget which is the case with several My-series books. Thus, besides writing about personal experiences, these books also offer an insight into the modern world, for example the series maps emigration tendencies during the last decade (an aspect more thoroughly discussed in Sedman 2016).

\section{Being on the Borders of the Genre}

In connection with the aspect of emigration it has been noted that actually the My-series books are not so much travelogues as emigration stories depicting the life in another country (Sedman 2015: 16). The traditional three-part structure leaving home, being somewhere and returning home - is usually present in the My-series books, although in several cases the last part of the trip - coming home - is postponed. The authors have remained living in the other country and/or are making additional trips within that big trip. The modern globalized world can also be characterised using the term permanent travel.

In association with that observation, the details concerning the genre should be discussed. The "gray area between "fiction" and "non-fiction" [...] has perennially concerned scholars of travel literature" (Clarke 2018: 6). The term 'travel literature' is "an overall thematic category (and not [...] a genre) that includes works of non-fiction and fiction" (Borm 2004: 18-19). Therefore, travel literature includes travel guides, travel novels, travelogues, etc., which are associated with travelling. The field is difficult to define as travel literature borrows from the memoir, journalism, letters, etc. (Youngs 2013: 1). It may be said that everything associated with the journey may be included (Youngs 2013: 8), which results in the possibility to define the same text as, for example, a memoir or a travelogue (in Estonian literature a good example is Esimene välisreis (The First Trip Abroad, 1945) by Friedebert Tuglas). While 'travel literature' is an overall term, a 'travelogue' is considered a genre located on the border of fiction and popular science literature, connecting both the subjective and objective side (Tavel 1986: 270). The more subjective the more it is akin to fiction, the more objective the more it is akin to popular science literature, which includes for example travel guides and scientific depictions of a country. A travelogue has been defined as "any narrative characterized by a nonfiction dominant that relates (almost always) in the first person a journey or journeys that the reader supposes to have taken place in reality while assuming or presupposing that author, narrator and principal character are but one or identical” (Borm 2004: 17). According to this definition,, the My-series books 
can be classified as travelogues, especially those that have the classic three-part structure discussed above.

In most cases these books have been classified as travelogues (or travel books) and have also been seen as "kind of a link between light reading and autobiographical literature" (Viires 2010: 277). At the same time these books have been classified belonging to a new type of biographical literature and the term 'memoirs in real-time' (Valdvee 2008) and also terms 'life writing' and 'experience book' (Petrone 2010) have been used. Experience literature ('kogemuskirjandus' in Estonian) is one of the tendencies characterising contemporary Estonian literature. These are the books on the borders of the genre (autobiography, memoirs, novel) where the author's personal viewpoint and experiences are in the centre. For example, the Estonian television journalist Vahur Kersna's Ei jäta elamata (Won't Give Up Living, 2014) about his battle with cancer, the media figure Aigi Vahing's Valik (Choice, 2010) about her personal struggles or Klaaslaps (A Glass Child, 2016) by one of the most notable contemporary Estonian writers Maarja Kangro about her ordeal trying to get pregnant and finally being forced to abort the baby for medical reasons. This kind of literature may be a form of therapy for the author and function as a self-help book for readers. Both this kind of literature and also the My-series books are very popular and constantly in top ten lists.

One of the reasons why the My-series books are so popular is definitely the above-mentioned "sincere look into the true world of oneself" (Petrone 2010). In the world centred around subjects, a considerable amount of readers is interested precisely in personal stories as stories and photos about oneself posted on social media are constantly liked. Actually, the My-series books can be considered as literary selfies - a person is portrayed setting the world as background. Analysing the popularity of the series, it has been noted that one of the reasons is the multitude of authors each having his/her unique style and personal story to tell. This enables the author to impress a wider audience as there are plenty of authors to choose from (Pesur 2013: 45). The other important factor is the fact that today more and more readers do not like long and complicated texts but prefer easily readable and simpler texts, which is definitely one of the characteristics of the series.

Each My-series book has a different dominant but they all have a travel component thus the specific definition whether the particular book is a classic travelogue or not could be made separately. In any case, fiction has a significant role as fictional techniques are used: plot, characterisation and dialogues (Youngs 2013: 4). Especially the latter indicates the role of fiction as it may be asked whether the author has an extremely good memory, has used 
KÕVAMEES

transcriptions or has moved around with a voice recorder (see also Tisdale 1995; Thompson 2011: 28). These variants are not impossible but unlikely as in the vast majority of travelogues dialogues are (re)constructions. Authors use the form of a dialogue as a narrative tool and readers cannot be certain that these conversations took place exactly the way described (see also Liiv 2012: 31).

Travelogues altogether are constructions as a certain choice has been made what to write about and how. "We're always choosing what we see, what we don't see, and whom we meet; we're always inventing our destinations" (Youngs 2013: 10). Even those descriptions that at first sight seem to be easy or unambiguous hide moral, ideological, theoretical, esthetical, etc. statements, judgements and meanings that often have a wider resonance (Liiv 2012: 82). "The scenes and incidents we encounter in a travelogue necessarily come to us in a filtered form, refracted first through the perceiving consciousness of the traveller, and secondly through the act of writing, the translation of 'travel experience' into 'travel text'” (Thompson 2011: 62). A travelogue is situated between fact and fiction, between subjective research and objective documentation (Holland, Huggan 2000: 11) but "travel writers do not have the same licence as novelists simply to make things up; to do so is to risk one's narrative being classified as fiction, or worse, as fraudulent" (Thompson 2011: 16). A travelogue that is too realistic and descriptive is boring (too close to a travel guide) while a travelogue that is too imaginative and metaphoric is a lie (too close to a novel) (Lisle 2006: 30 ), thus a travelogue is on the borders of the genre.

\section{Conclusion: Catching the Spirit of Time}

The authors of the My-series books have a very different background representing various fields and experiences - the diversity has been one of the major principles of the series. These books offer readers a possibility to travel in various places and also to get to know other people's stories. In the contemporary world where everything appears to be seen and discovered and there seems to be no undiscovered places, the My-series books offer the possibility to experience the world from a different angle. On one hand, the series offers the possibility to read about countries and people, gives instructions and advice for travellers, thus filling the role of a travel guide; on the other, the series offers the possibility to either identify oneself with the author or empathise with the happenings and ordeals of the author similarly to the social media channels or reality shows. The phenomenon of the series may be explained by its versatility: it has an array of authors from different fields depicting various places. 
This type of experience literature can function as a form of therapy for both the author and the reader. The exact genre of this type of books is not always clear, although the My-series books are predominantly labelled as travel literature. In the me-centred society genres are also shaped to fit the needs of an author, thus the borders between genres are blurred. The My-series books could also be labelled as literary selfies as the author portrays her/himself setting the world in the background. The language used in these books is not complicated, which also attracts wider audiences who prefer texts that are easy to read. The archetypical structure of the stories - going out to the world and finding one's happiness - is another element in the formula for success.

Thus, it may be concluded that the My-series represents several tendencies characteristic of the era: the subjectivity or me-centeredness, uncomplicated and simple language, the experience of an author that is shared with readers, the component of a self-help, the democratization of literature and being on the borders of genres. At the same time in these books several important topics are discussed, for example the mobility and emigration of Estonians and the globalizing world. It general it may be noted that the series has caught the spirit of time, which explains its popularity.

\author{
Anneli Kõvamees \\ anneli.kovamees@tlu.ee \\ Tallinna Ülikool \\ Humanitaarteaduste instituut \\ Narva mnt 29 \\ 10120 Tallinn \\ EESTI / ESTONIA
}

\title{
References
}

Alari, A. 2012. Minu Inglismaa. Vana ja hea. Tartu: Petrone Print.

Borm, J. 2004. Defining Travel: On the Travel Book, Travel Writing and Terminology. G. Hooper, T. Youngs, eds., Perspectives on Travel Writing. Aldershot: Ashgate, $12-26$.

Butor, M. 2001. Travel and Writing. - Susan L. Roberson, ed., Defining Travel. Diverse Visions. Jackson: University Press of Missisipi, 69-87.

Callahan, M. 2007. Eat, pray, loathe. - New York Post, 23.12, http://nypost.com/ 2007/12/23/eat-pray-loathe/ (28.01.2016).

Cantrell K. 2011. Eat, pray, loathe: women's travel memoir as moving metaphysical journey or narcissistic new-age babble? - Ejournalist: A Refereed Media Journal, Vol. 11, No. 1, 45-53. 
KÕVAMEES

Clarke, R. 2018. Toward a Genealogy of Postcolonial Travel Writing. - R. Clarke, ed., Postcolonial Travel Writing. Cambridge University Press, 1-15.

Gerhold, P. 2012. Minu Brasiilia. Sipelgajaht vihmametsas. Tartu: Petrone Print.

Hellerma, K. 2009. Avanevad uksed: eestlasest maailmakodanikuks. - Sirp, 20.08, http://www.sirp.ee/index.php?option=com_content\&view=article\&id=9207: avanevad-uksed-eestlasest-maailmakodanikuks\&catid=7:kirjandus\&Itemid= 9\&issue $=3263$ (10.10.2017).

Hennoste, T. 2009. Mälu ja elu. Grilliajastu kirjandus. - Looming, 9, 1271-1280.

Holland, P., Huggan, G. 2000. Tourists with Typewriters. Critical Reflections on Contemporary Travel Writing. Michigan: The University of Michigan Press.

Kahu, K. 2011. Minu Guatemala. Maa, kus vikerkaar saab oma värvid. Tartu: Petrone Print.

Kallas, K. 2012. Minu Vietnam. Maailmakodanik, seljakott ja beebi. Tartu: Petrone Print.

Kõvamees, A. 2013. Nullindate reisikirjad: minu-vaated maailmale. - Methis, 11, 8496. https://doi.org/10.7592/methis.v8i11.1003

Kõvamees, A. 2017. Petrone Prindi „Minu“ sari: selfie-ajastu kirjanduse kaardistusi. Philologia Estonica Tallinnensis, 2, 129-145. https://doi.org/10.22601/PET.2017. 02.07

Liiv, K. 2012. Antropoloogiline vaade Petrone Printi reisiraamatute sarjale: „Minu Maroko“, „Minu Nepaal“ ja „Minu Argentina“. University of Tartu [MA Thesis]

Lisle, D. 2006. The Global Politics of Contemporary Travel Writing. Cambridge University Press.

Merusk, M. 2012. Minu Sitsiilia. Maffia kohta mitte küsida! Tartu: Petrone Print.

Nielsen, K. 2013. Minu Kopenhaagen. Jalgrattarapsoodia. Tartu: Petrone Print.

Pesur, L. 2013. Minu-sarja fenomen „Minu Eesti“ ja „Minu Ameerika“ põhjal. Tallinn University [BA Thesis]

Petrone, E. 2010. „Minu“ sarja fenomen. - http://vildereisid.files.wordpress.com/2010/ 10/minu-sarja-fenomen.pdf (20.03.2017).

Petrone, J. 2011. Minu Eesti 2. Mida sa tahad? Tartu: Petrone Print.

Praakli, K. 2009. Minu Itaalia. Kõige kirglikum ja kaootilisem. Tartu: Petrone Print.

Roose, M. 2011. Minu Amsterdam. Normaalne on piisavalt hull. Tartu: Petrone Print.

Rudi, H. 2014. „Minu...“ raamatute sari kui moodsa maailma eestlase portree. Postimees, 8.12, http://kultuur.postimees.ee/3019343/minu-raamatute-sari-kuimoodsa-maailma-eestlase-portree (28.01.2017).

Salong, H. 2010. Epp Petrone: olen huvitatud raamatu „Minu Saaremaa“ avaldamisest. Meie Maa, 13.11, http://www.meiemaa.ee/index.php?content=artiklid\&sub=6\& artid=39477 (27.12.2010).

Sanders, J.; Barnes-Brown, D. 2010. Eat, pray, spend: priv-lit and the new, enlightened American dream. - Bitch Magazine. Spring, http://bitchmagazine.org/article/eatpray-spend (28.01.2016).

Sedman, K. 2015. Eestlane Euroopas. Eestlaste endakuvand Lääne-Euroopas Petrone Prindi „Minu“-sarja näitel. University of Tartu [MA Thesis]. 
Mapping the Estonian Literature of the Selfie-era

Sedman, K. 2016. Elust välismaal „Minu“ vaatenurgast. - https://www.muurileht.ee/ elust-valismaal-minu-vaatenurgast/ (26.01.2017).

Stavans, I., Ellison, J. 2015. Reclaiming Travel. Durham, London: Duke University Press.

Stein, J. 2013. Millennials: The Me Me Me Generation. - Time, 20.05, http://time. com/247/millennials-the-me-me-me-generation/ (22.09.2019).

Tavel, L. 1986. Reisilt reisiraamatusse. - Keel ja Kirjandus, 5, 270-279.

Thompson, C. 2011. Travel Writing. New York: Routledge.

Tiidenberg, K. 2015. Image Sharing, Self-Making and Significant Relationships: Understanding Selfie-Practices. Tallinn University [PhD Thesis].

Tisdale, S. 1995. Never let the locals see your map. - Harper's Magazine, Vol. 291 (1744), http://ehis.ebscohost.com.ezproxy.tlu.ee/ehost/detail?vid=3\&hid=124\&sid= 454c4db2-be14-4841-809b-3ca157f9d440\%40sessionmgr114\&bdata=JnNpdG U9ZWhvc3QtbGl2ZQ\%3d\%3d\#db=a9h\&AN=9508283372 (26.01.2016).

Urry, J. 2002. The Tourist Gaze. 2nd ed. London, etc.: Sage Publications.

Valdvee, K. 2008. Uutmoodi elulookirjandus: mälestused reaalajas. - Sakala, 16.08, http://www.sakala.ajaleht.ee/180808/esileht/artiklid/5035841.php (18.01.2011).

Vela, H. 2012. Minu Albaania. Paradiis ja põrgu. Tartu: Petrone Print.

Viires, P. 2010. Twilight zone. Nullindad kui hämarala. - Looming, 2, 273-282.

Yano, M. 2013. Minu Tōkyō. Nähtamatu piiri taga. Tartu: Petrone Print.

Youngs, T. 2013. The Cambridge Introduction to Travel Writing. Cambridge University Press. 